\title{
技術報 告
}

\section{精紡機のトップローラの無注油化に関する実験”}

\section{1. まえがき}

精紡機のドラフト部のローラの無注油化については, すでに種々検討がなされている.昭和 30 年綿紡技術研究 所での研究課題「精紡機トップローラの無注油化」と してとりあげられており，かなり長期にわたる現場実験 の貴重な資料も出ている，その結論中ころがり軸受型口 ーラのすぐれた無注油特性が確認されたことはもちろん であるが，含油性合成樹脂ローラもかなり長期の無注油 の使用に耐えることが認められて括り, 特に摩擦トルク の大小抢よび変動は系質にはあまり影響せず，ローラが 烺付かないかぎり満足な結果が得られることが強調され ている。したがって合成樹脂ローラの軽量で取报いの便 利な点, ルーズ ボス ローラの構造上の簡単な点, 経済 的に安価な点など, その無注油化の可能限界および寿命 いかんによってはその利用価值も十分あるものと考光ら れる、しかし合成樹脂にも種々あり，午の選択は重要で あるから適正なローラ材質, アーバ材質の組合せおよび 潤滑油が決められなければならない。本論文はローラ 材，アーバ材，潤滑油をいくつか組合せて実用に近い条 件沉て摩耗, 潤滑能力を調べ無注油化の可能限界を研究 したものである。

\section{2. 試 験 方 法}

試験装置は第 1 図のごとく 3 線式の実験装置（精紡機 ローラ状態と同様) で, $A, B$ はトッフローラ, $C, D$ はアーバボトムローラ $E$ は歯車 $G$ より駆動される. 荷重 $W$ はレバ $I$, 支点 $J$ によローラ $F$ を全して $A$, $B$ へ伝わる.アーパ $C, D$ はオーバ ハングした支持具 $H$ に固定されている．Fは試験トップローラ $A$ 打よび $B$ に所定の荷重を与えるべく設けたボールペアリング 入りローラである. 摩耗測定はセル内径はシリンダゲ ージアアーバ外径はマイクロメータを用い，6 個所測定

$\begin{array}{llll}\text { 川 } & \text { 崎 } & \text { 景 } & \text { 民** } \\ \text { 福 } & \text { 永 } & \text { 夏 } & \text { 雄 } \\ \text { 楜 } & \text { 沢 } & \text { 利 } & \text { 一 }\end{array}$
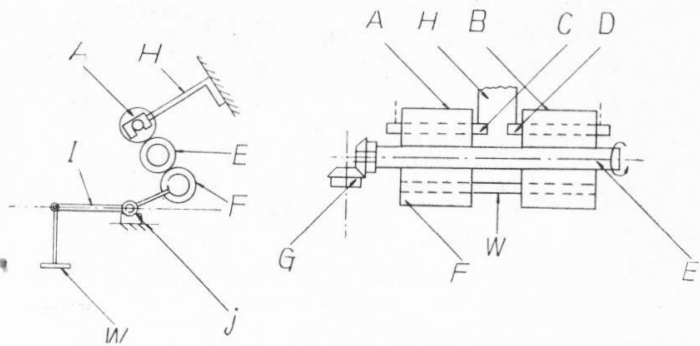

（第1図）試 験 装置

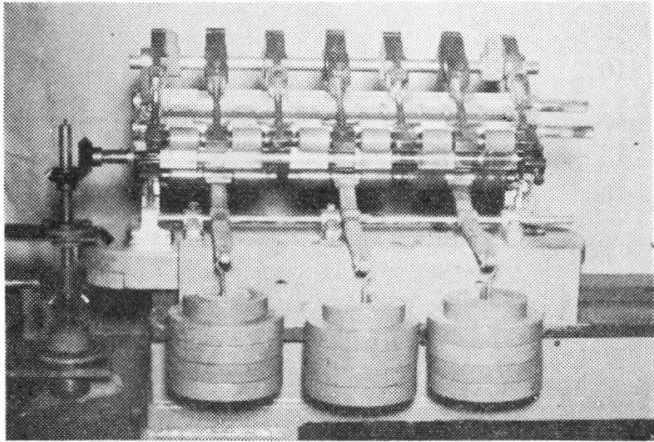

（第 2 図）試験装固

し、それぞれの平均值を寸法孪化とした。その他潤滑油 の量と変色状態を観察した．第 1 回 $460(\mathrm{hr})$, 第 2 回 720 (hr) では各潤滑油の油量と変色を観察し, 第 3 回 $960(\mathrm{hr})$ ，第 4 回 2160 (hr) ではその他に寸法を測定 した・測定に際しては、セルおよびアーバはペンゾール を用いて洗浄して行なった。

3. 運転条件とセル，アーバ材質および 潤滑油 (剂) の組合せ

（1）実験条件（I）

連続運転時間 $2160 \mathrm{hr}$

回 転 数 225 r.p.m. (42 m/min)

荷重 $4.5 \mathrm{~kg}\left(3.1 \mathrm{~kg} / \mathrm{cm}^{2}\right)$

* Experiments on Non-oiling of Top-rollers on Spinning Frames.

米 K. Kawasaki, 東京大学工学部, N. Fukunaga, R. Kurumizawa, 日本ォイレス工業株式会社 
武 片 寸法 $6.1 \phi \times 25 \ell$

潤滑当初注油以後無注油連続運転

(2) 表験条件:（II）

連綂運転時閶 $960 \mathrm{hr}$

回転 数 225 r.p.m. $(4.95 \mathrm{~m} / \mathrm{min})$

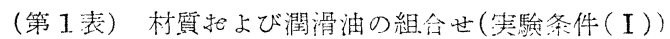

\begin{tabular}{|c|c|c|c|}
\hline 潘号 & セ & アーバ & 潤滑油 \\
\hline 1 & ナイロンバーク & 铸跳 & A \\
\hline 2 & $"$ & ナイロン & A \\
\hline 3 & 含油性含成樹脂 (I) & 鏣跌 & $\mathrm{B}$ \\
\hline 4 & " & ナイロン & $\mathrm{B}$ \\
\hline 5 & " & 鋳铁 & A \\
\hline 6 & " & ナイロン & A \\
\hline
\end{tabular}

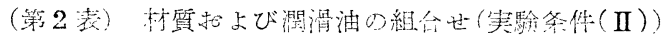

\begin{tabular}{|c|c|c|c|}
\hline 番: 㕺 & セ & $\vec{\gamma}-ハ ゙$ & 潤滑油 \\
\hline 7 & ナイロンベーク & 鋳 & $\mathrm{C}$ \\
\hline 8 & 含油性会戎赭脂（II） & " & $\mathrm{D}$ \\
\hline 9 & " & " & $\mathrm{E}$ \\
\hline 10 & " & " & $\mathrm{F}$ \\
\hline 11 & " & ナイロン & $\mathrm{D}$ \\
\hline 12 & " & $"$ & $\mathrm{E}$ \\
\hline 13 & " & 鉃 & $\mathrm{A}$ \\
\hline
\end{tabular}

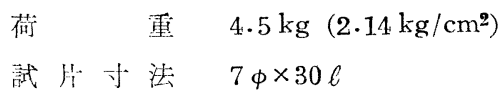

潤滑当初注油以後無注油連続運転

この荷重およびすべり速度はスーパハイドラフト精 紡機、フロントトップローラの実際に近い条件を採用 した。（第 2 表参照)

(第 3 表) 寸 法 变 化 (故径 $\mathrm{mm}$ )

\begin{tabular}{|c|c|c|c|c|}
\hline 武片番号 & セ $\quad$ U & アーバ & $\begin{array}{l}\text { アーバ } \\
+ \text { +セル }\end{array}$ & $\begin{array}{c}\text { 備 考 } \\
\left(\begin{array}{c}\text { 連転時間) } \\
(\mathrm{hr})\end{array}\right.\end{array}$ \\
\hline 1 & 0 & 0.001 & 0.001 & 2160 \\
\hline 2 & 0.005 & 0.007 & 0.012 & 2160 \\
\hline 3 & 0.001 & 0.001 & 0.002 & 2160 \\
\hline 4 & 0.009 & $0.095^{k}$ & 0.104 & 2160 \\
\hline 5 & 0.009 & 0.002 & 0.011 & 2160 \\
\hline 6 & 0.006 & 0.006 & 0.012 & 2160 \\
\hline 7 & 0.010 & 0.004 & 0.014 & 960 \\
\hline 8 & 0.050 & 0.020 & 0.070 & 980 \\
\hline 9 & 0.010 & 0.007 & 0.017 & 960 \\
\hline 10 & 0.008 & 0.008 & 0.016 & 960 \\
\hline 11 & 0.010 & 0.008 & 0.018 & 960 \\
\hline 12 & 0.008 & 0.010 & 0.018 & 960 \\
\hline 13 & 0.005 & 0.005 & 0.010 & 980 \\
\hline
\end{tabular}

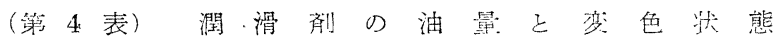

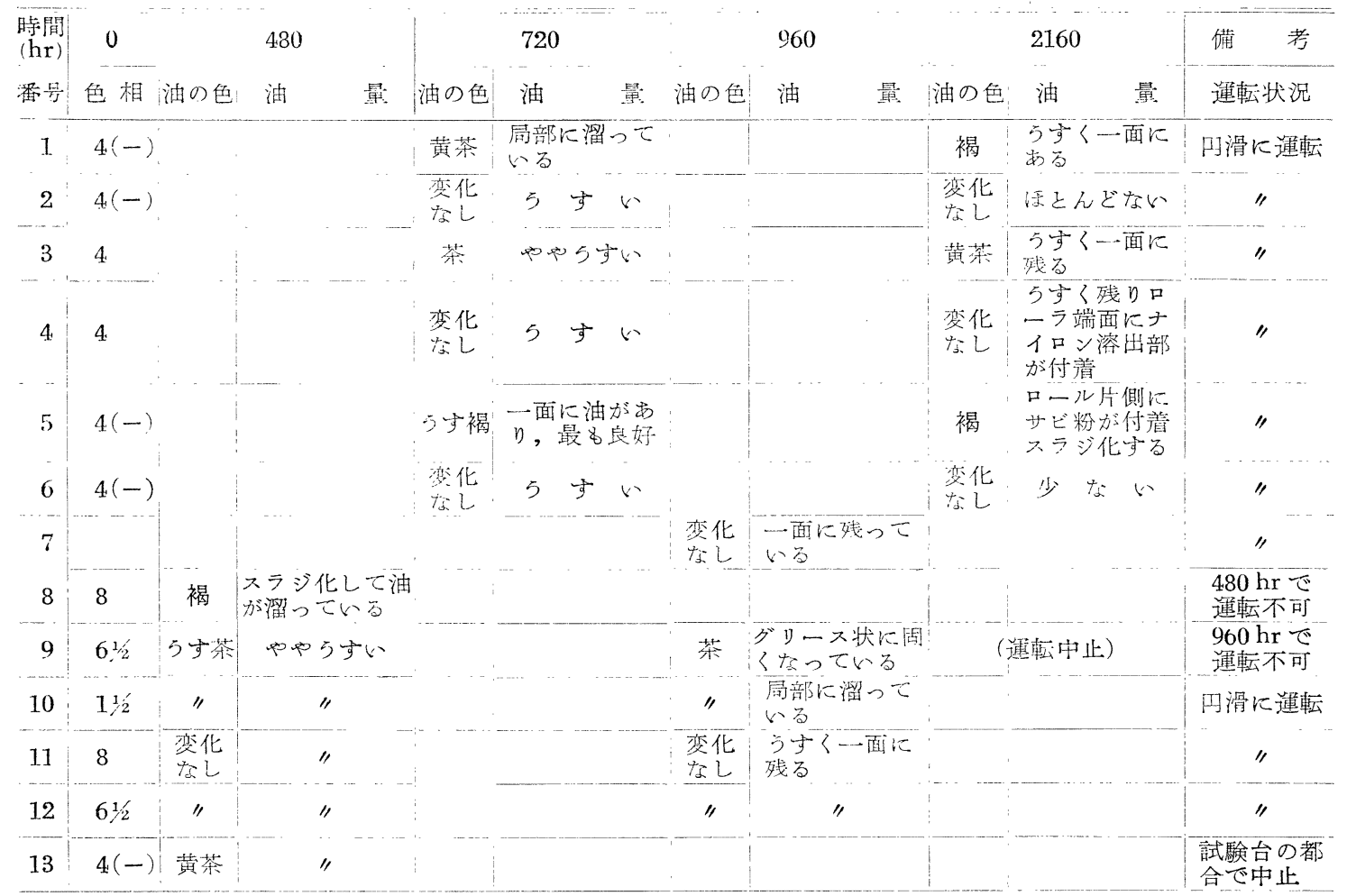




\section{4. 実 験 結 果}

（1）才法栄化

江变化は第 3 表に亦す通り 試片の1-6では4党の枈き， セル，アーバとも内径执よび外 径の寸法变化は 1000 分台で摩 耗㮦はわずかである。また試片 8 をのぞき $7,9,10,11,12$, 13 は 1000 分台以下のオーダ であり，一般に含油性:合成樹脂 （I）の方汴同（II）に比し摩 耗は少ない。

（2）㵎滑油の油量と变色状 態

(第 4 表参照)

\section{5. 考察}

含油性今成樹脂口ーラ0)寿命

は潤滑莇の良否が大きな网子として效いてくる，合成樹 脂ローラでは熱伝尊が热い上に，一定少量の潤滑油がく りかえし摩擦をらけるため油の少化，変質が起りやすく 摩摖面の保護能力を失い，摩轮を促進し油のスラジ化の 傾向を進めることになる。しかし実験の結果ナイロンア 一バとの組合せは鋳鉄アーバとの組合せにくらべ摩摖熱 のこもりが大きいにもかかわらず油の变質はおこらず， 当しろ鋳鉄アーバの方が快なばしいこのことは鋳 鉄ア一バとの組合せの場合金属酸化物の触媒として油の 灵澌を促進させる働きの影響のおが大きいことを意味す る、また恋質した㵎滑油のほとんどより鉄分が検出され
(第 5 表) セル村質の物理的機械的性質

\begin{tabular}{|c|c|c|c|c|}
\hline 称 & 位 & $\begin{array}{l}\text { ナイロンベーク } \\
\left(\begin{array}{l}\text { 日本オイレス } \\
\text { 中 } 280 \text { 相当品 }\end{array}\right)\end{array}$ & $\begin{array}{c}\text { (含油性会戌樹脂 } \\
\left(\begin{array}{l}\text { 日本才インス } \\
\text { 出 } 200 \text { 相当品 }\end{array}\right)\end{array}$ & $\begin{array}{c}\text { 含油性合成樹脂 } \\
\text { (II) } \\
\left(\begin{array}{l}\text { 日本オイレス } \\
\$ 250 \text { 相当品 }\end{array}\right)\end{array}$ \\
\hline 抗 張 力 & $\mathrm{kg} / \mathrm{mm}^{2}$ & $8-10$ & $5 \cdot 5$ & 8 \\
\hline 压：縮 強 度 & $\mathrm{kg} / \mathrm{mm}^{2}$ & 25 & $22-23$ & 28 \\
\hline 抗 折 少 & $\mathrm{kg} / \mathrm{mm}^{2}$ & 11 & 11 & 15 \\
\hline 衝 繋 值 & $\mathrm{kg}-\mathrm{cm} / \mathrm{mm}^{2}$ & 0.36 & 0.36 & 0.55 \\
\hline 摩擦 係 数 & $\mu$ & 0.013 & 0.015 & $0.01-0.04$ \\
\hline 耐 摩 耗 性 & & 大 & 六 & 大 \\
\hline 比重 & & 1.30 & 1.37 & 1.40 \\
\hline 熱 膨 張 率 & $\times 10^{-5} /{ }^{\circ} \mathrm{C}$ & 3.7 & - & 2 \\
\hline 磎 性 係 数 & $\times 10^{4}$ & $8 \cdot 5$ & 8 & 8 \\
\hline 熟 伝 遵率 & $\mathrm{kcal} / \mathrm{mhr}^{\circ} \mathrm{C}$ & 0.02 & 0.03 & 0.04 \\
\hline 加工. 珄 & & 良好 & 良好 & 泉好 \\
\hline 含 油 量: & wt $\%$ & - & 3 & 2 \\
\hline 許容最高荷重 & $\mathrm{kg} / \mathrm{cm}^{2}$ & 70 & 100 & 100 \\
\hline 許容最高周速 & $\mathrm{m} / \mathrm{min}$ & 900 & 900 & 900 \\
\hline 許容 P V 值 & $\mathrm{kg} / \mathrm{cm}^{2} \times \mathrm{m} / \mathrm{min}$ & $800-900$ & 1000 & 1000 \\
\hline 使用限界温度: & ${ }^{\circ} \mathrm{C}$ & 100 & 100 & 100 \\
\hline
\end{tabular}

たことからもらなずける。したがって鋳鉄アーバの組令 せについては，その油の選択は慎重にする必要があり， とくにせん断安定性の大きく，酸化しにくい油が望まれ る.一方ナイロンアーバの場合, 潤滑油の吸着能力か らみてもわかると和り，油の保持能力は鋳鉄アーバにく らベおとり，摩擦表面の油が压力でおしだされやすく， この点粘性の高いものを選ぶことが必要である。また一・・ 部の潤滑油ではナイロンを溶かすものも認められる。し たがってナイロンアーバの聞滑油選扒にはての点も考 虑に入れなければならない,ナイロンベークローラは 乾燥摩擦をたてまえとしているが，なじみ時の給油はむ

(第 6 表)

潤

滑

削

\begin{tabular}{|c|c|c|c|c|c|c|c|}
\hline $\begin{array}{rr} & \text { 潤 } \\
& \text { 項 }\end{array}$ & 滑 㓩 & $\begin{array}{c}\text { ゴールデン } \\
\text { スロール30番 } \\
\text { (A) }\end{array}$ & $\begin{array}{c}\text { バーデン } 2 \text { 番 } \\
\text { (B) }\end{array}$ & $\begin{array}{l}\text { パウダ リュ } \\
\text { ブ } \\
\quad \begin{array}{l}2 \\
(\mathrm{C})\end{array}\end{array}$ & $\begin{array}{c}\text { 機械摺動部潤 } \\
\text { 滑油L-8715A } \\
\text { (D) }\end{array}$ & $\begin{array}{c}\text { バクトラ } 2 \text { 采 } \\
\text { (E) }\end{array}$ & $\begin{array}{c}\text { 織機油 } 104 \text { 号 } \\
\text { (F) }\end{array}$ \\
\hline 比重 & $15 / 4^{\circ} \mathrm{C}$ & 0.8888 & & 固体潤滑昘 & 0.9434 & 0.924 & 0.8878 \\
\hline 色 & & 4. $(-)$ & 4 & & 8 & $6 \frac{1 / 2}{2}$ & $11 / 2(-)$ \\
\hline 引火点 & ${ }^{\circ} \mathrm{C}$ & 250 & 190 & $\left\{\begin{array}{l}\text { 稀有金属之脂 } \\
\text { 配酸の化物 }\end{array}\right.$ & 162 & 179 & 244 \\
\hline 粘 $\left\{\begin{array}{r}37.8^{\circ} \mathrm{C} \\
98^{\circ} \mathrm{C}\end{array}\right.$ & $\begin{array}{l}\text { CS (SUS) } \\
\text { CS (SUS: }\end{array}$ & $\begin{array}{r}111.4(516) \\
11.55 .64 .9)\end{array}$ & 236.7 & & $\begin{array}{c}7549(349.9) \\
8.49(54.13)\end{array}$ & $\begin{array}{r}(325) \\
(54.5)\end{array}$ & $\begin{array}{r}76(352.2) \\
9.26(56.8)\end{array}$ \\
\hline 粘度指数 & & 99.1 & & & 89.2 & - & 106 \\
\hline 流 動 点 & ${ }^{\circ} \mathrm{C}$ & -12.5 & -14 & & -20 & -17.5 & -12.5 \\
\hline 防錆 & & - & - & - & - & - & 合格 \\
\hline 起 泡 & & 合 格 & - & - & - & - & - \\
\hline 添加成 & & 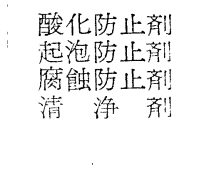 & & & $\begin{array}{l}\text { 酸化防止斉 } \\
\text { 起泡防止斉 } \\
\text { 極王添加剂 }\end{array}$ & 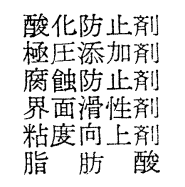 & 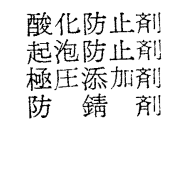 \\
\hline
\end{tabular}


必要であり，その点固体潤滑剤の使用はナイロンベー クの乾燥摩擦特性を生かするのとして有効である.

摩擦特性から見てもナイロンベーク，鋳鉄ア一バの 組合せは良好で，これに固体潤滑剤を用いれば完全な乾 燥摩擦での使用が可能である．含油性合成樹脂ローラと しては負荷条件から見ても機械的强度より含油量のでき るだけ多い材質を選ぶ力が無注油における耐久性は期待 できる・したがって含油性合成樹脂（I）とナイロンア

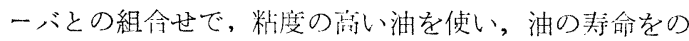
ばして使用すれば, 2500-3000 hr（1日 $16 \mathrm{hr}$ として 5 グ月）以上の無給油がフロントトップローラとしてい门 能でする。

\section{6. 試料 の 性 質}

セル材質の物理的性質は第 5 表，潤滑油の特性は第 6 表の通りである.

\section{7.むす ず}

以上を総括すれば，含油性怠成樹脂ローラとしてて含油 量のできるだけ多い材䆩を選び，ナイロンフーバとり 組命せで用いることが㪛いとの結諭が得られる・フッン トトップローラの鱼荷条件では彗用上会成樹脂口ーラ の使湖的能であり，七ル材質，アーバ材質および潤㳙 油の組今せを適Fに選べば慜注:油時間 2500-3000 hr

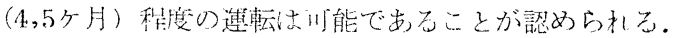

